Sultan Qaboos University Journal of Arts \& Social Sciences
جامعة السلطان قابوس

مجلة الآداب والعلوم الاجتمأعية

\title{
The Effect of Geographic Constraints on the Academic Achievement of Students at King Saud University Using GIS Techniques: A Case Study
}

\begin{tabular}{c}
\hline Mofareh Qoradi \\
\hline Assistant Professor \\
Geography Department \\
King Saud University \\
mufarehq@ksu.edu.sa
\end{tabular}




\title{
The Effect of Geographic Constraints on the Academic Achievement of Students at King Saud University Using GIS Techniques: A Case Study
}

\author{
Mofareh Qoradi
}

Abstract:

This research studied the effect geographic constraints of students' daily journey to King Saud University (KSU) on their learning achievement, their participation in extracurricular activities, and their visit of the university library. The data was collected from a random sample of KSU students that consisted of 854 students via an online survey during the academic year 2016. The technologies of geographic information systems have been employed to build a spatial model to measure the distance and taken time for the daily student drive from their houses to the university. $30 \%$ of the students' houses are at a $20 \mathrm{~km}$ distance from KSU, 35\% of the students need about 40 minutes to arrive at the university, and $8 \%$ who need about one hour to arrive. Since Riyadh is urbanized, high in population density, and has a lot of traffic, theses distances and time students spend in their daily drives to the university are causing stress and exhaustion and affect students' academic achievement. $68.42 \%$ of students indicated that the location of their homes affects their learning achievement and $63.95 \%$ answered that it affects their attendance of activities in the university. Regarding visiting the library, about 58.16 responded that location of their homes affects library visits. The study clarified that there is a negative correlation between the students' delay times and their academic rate, in other words as the delay times increase, students GPAs decline and subsequently, their academic achievement is less. Finally, the study suggested to specifying and rescheduling the work times for employees and students in Riyadh to reduce the daily drive times, the environmental pollution, and economic depreciation and help increase students' academic achievement by delaying the official working hours for Higher Education institutions by an hour; to start at 9.00 a.m. instead 8.00 a.m. as is currently the case. Keywords: Geographic constraints; Drive time; Academic achievement; GIS.

\section{استخدام نظم المعلومات الجغرافية لقياس تأثير القيود الجغرافية

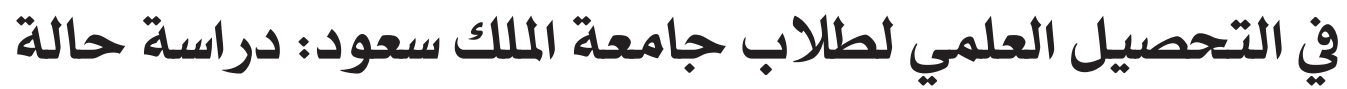

\author{
مفرح قرادي
}

تناولت هذه الدراسة قياس تأثير المعوقات الجغرافية للرحلة اليومية لطلبة جامعة الملك سعود على تحصيلهم العلمي، ومشاركتهم في

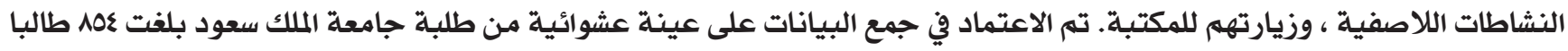

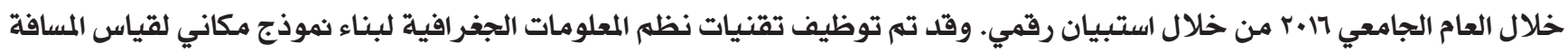

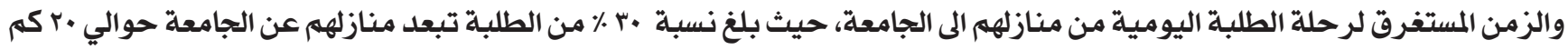

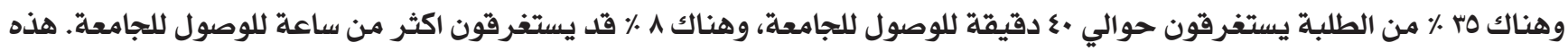

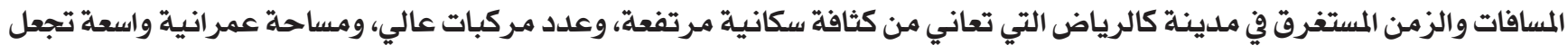

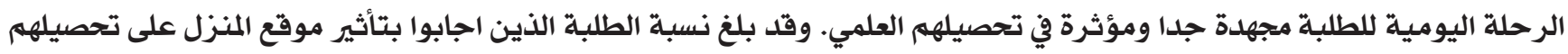

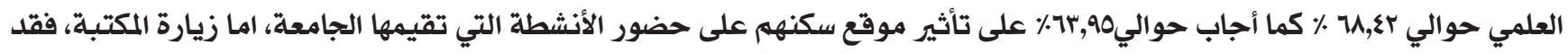

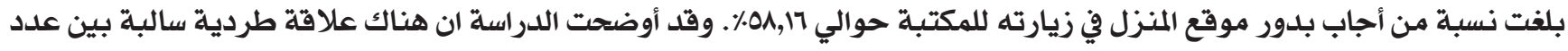

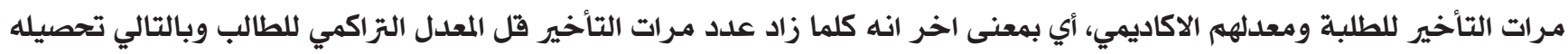

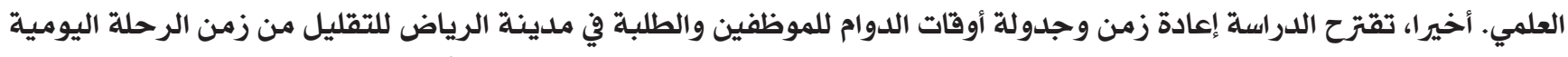

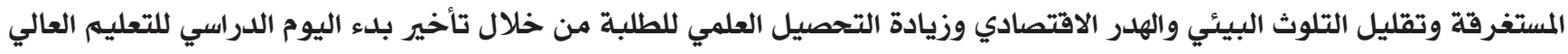
ساعة واحدة بحيث تبدأ الساعة 9 صباحا بلدلا من الثامنة صباحي ولها حاليا. الكلمات المفتاحية: معوقات جغرافية؛ زمن الرحلة؛ التحصيل العلمي؛ نظم المعلومات الجغرافية. 


\section{Introduction and Background:}

Geographic constraints affect the economic, health, and security fields in many ways including geographic distribution and the quality of supplied services. Therefore, it affects people's lives. Many studies discuss these effects, related factors, and possible solutions to reduce them. However, studies on the effects of geographic constraints on education and academic achievement from a geographic perspective are rare in Arab countries and worldwide. Many students live in Riyadh, one of the most rapidly growing cities in the world in terms of population and urbanization. In this city, about 6 million people (General Authority for Statistics, 2015) live in an area measuring 2395 km2 (High Commission for the Development of Riyadh, 2015). Consequently, an increasing number of journeys in the city have been generated: up to six million daily in 2010 (Alhussien, 2011). According to the statistics of 2005, private cars constitute around $84 \%$ of the total transportation in Riyadh, resulting in many transport-related problems such as traffic jams and congestion, which affect students' daily journeys to universities and colleges in the city. The daily journey of students and the time taken to arrive at their universities and colleges greatly affect their academic achievement in terms of attending lectures on time, visiting libraries, and attending workshops. It also affects students' participation in extracurricular activities such as sports, student clubs, and volunteering activities. Card (1995) found that those residing nearby universities have admitted to more years in education than those residing far away, because of little effects of geographic constraints. Falch et al. (2011) studied the effect of geographic location on students' academic achievement. Their study used detailed information about the real time spent journeying between students' houses and schools in Norway, recommending that shorter daily journeys have a positive effect on academic achievement, leading to early graduation.

In the United States of America, Do (2004) and Griffith and Rothstein (2009) revealed that the opportunity for poorer students to attend governmental universities increases if they live near the university. Similarly, Sa et al. (2006) noted that the geographic distance to vocational universities and colleges increases the probability of school graduates continuing their education beyond high school in the Netherlands. Based on their study on students from the United Kingdom, Gibbons and Vignoles (2009) concluded that the distance from their houses to their schools affects the selection of the closest college or university. The greater distance to nearest education institution has a significant impact on the decision to continue in fulltime post-compulsory education: especially in rural areas relative to urban areas (Dickerson and Mclntosh, 2010). Using detailed geographical data from Sweden, Kjellström and Regnér (1999) find that higher distance between area of residence and nearest university has a small but statistically significant negative effect on university enrolment. Finally, Park (2012) revealed that distance was the most important factor when visiting public libraries in addition to other factors such as race, education level, and other demographic variables.

This study is based on calculating the time and distance of the daily journey of students at King Saud University (study sample) in Riyadh from their houses to the university. Furthermore, the spatial distribution pattern and its direction in the city are analyzed, and the impact on students' learning achievement and participation in university activities are measured based on geographic information systems (GIS).

\section{The Research Problem:}

Riyadh has witnessed many developmental projects, particularly in public transportation, which has increased traffic congestion and journey time to the city, as many people use their own cars. The absence of public transport in Riyadh, the high population, and wide urban area complicate people's journeys to work and take much time, especially for university students using their own cars to attend university. This research studied students at King Saud University, which is located in the west of the city. Its location increases the difficulties experienced by students residing in the west and south of the city in reaching the university. This has increased students' delays in attending lectures, especially those scheduled in the morning, which affects their academic achievement. Further to the amount of time spent on students' journeys, some might not participate in extracurricular activities held by the university or visit the library. This study attempts to investigate this situation to find appropriate solutions.

Students at King Saud University in Riyadh experience a long daily journey to and from the university. This is exacerbated by the city's working hours, as all authorities, employees, public and higher education students, and some private sector institutions start at the same time $(8: 00 \mathrm{am})$. Consequently, there are many vehicles on the roads, causing high traffic 
congestion and affecting people's arrival time at their workplaces and universities. This results in economic depreciation, lower academic achievement among students, and other environmental problems. This paper studies these factors from a geospatial perspective, using GIS to measure the effects of geographic constraints faced by students at King Saud University in their daily journey to the university on academic achievement, extracurricular activities, and visiting the university library.

\section{Objectives:}

The study aims to measure the effects of geographic constraints of students' daily journey to the university on their academic achievement, participation in extracurricular activities, and visiting the university library. The objectives of the study were achieved as follows:

1. A spatial model was constructed to measure the time and distance of the daily journey of students at King Saud University based on a GIS network analysis.

2. The relationship between the number of times delayed because of distance and students' academic achievement was determined.

3. The effect of geographic location on students in Riyadh and their obligation to attend lectures, visit the library, and participate in various university extracurricular activities was identified.

\section{Methodology:}

\subsection{Data Collection}

This study was conducted on a random sample of students at King Saud University, including those at all levels of study in all academic disciplines in the academic year 2016. The participants in the study were 854 students (380 male, 474 female).

\subsection{Procedures}

Through a questionnaire, a geographic database was constructed for all sites of the participants according to the districts in Riyadh to identify density and spatial distribution. The study applied a network analysis to calculate the time taken to reach the university as in Falch et al. (2011), as this is an important issue affecting student academic achievement. The high number of participants responding to the questionnaire meant that the statistical correlation had to be determined between the effect of student residence location on learning achievement through the GPA and the number of times students were delayed for lectures. In addition, the statistical correlation between housing location and student participation in extracurricular activities at the university was clarified through a Spearman analysis.

\subsection{Question}

Is there a significant relationship between the number of times of delays due to students' location being a far distance away and academic achievement?

\section{Results:}

Table (1) shows the age categories of the participants in the study. The age category 18-25 years represents about $87 \%$ of the participants, most of who are bachelor students. This is beneficial for the study, because they attend the university daily, which helps to achieve the study objectives.

Around $90 \%$ of participants are enrolled in a bachelor's degree program Figure (1). This may reflect the university's large number of bachelor students, who comprise the highest percentage of enrollments of all academic levels.

Table (2) shows The number of participating students from different colleges. Most participants are studying in the colleges of Pharmacy, Architecture and Planning, and Applied Medical Sciences. However, these participants do not represent the highest percentage of students in colleges at the university.

To study the effect of the geographic location of students' housing, their academic rates during the latter semester first need to be identified. Table (3) clarifies the academic rates of the participants in the study, showing that most (48.18\%) obtained excellent grades.

Figure (2) shows the geographic distribution of students in Riyadh. The density of students in certain districts, especially in the southwestern and eastern districts, is evident. In addition, Figure (3) shows that the density is focused in four districts, namely Dhahrat Albadea, Alsewedi, Alnaseem, and Alzizeyah.

The housing location relative to the university has an effect on students' obligation to attend lectures. As such, Table (4) indicates that $68.42 \%$ of participants responded "yes" to a question on housing location, confirming this factor's role in their obligation to attend lectures. Around $31.58 \%$ noted that housing location had no effect on obligation to attend lectures. Furthermore, housing location affects students' attendance of university activities and visiting the library and other facilities, although this percentage is lower than for previous activities, perhaps because university activities and visiting the library usually 
occur in the evening and do not have specific times for attendance. These results support research on the importance of studying the effect of spatial distance on students' academic achieveme

Students' total number of times delayed was surveyed, because these delays may affect academic achievement by students missing important information, blurring ideas based on not attending the full lecture, and distracting the lecturers and other students. Table (5) indicates that 3.19\% of the participants were late more than 5 times a week, $26.99 \%$ were late $2-3$ times a week, and $44.19 \%$ were late once a week. These percentages are high and can affect students' academic achievement. Therefore, this must be considered when studying academic

Table (1) Age categories of participant students

\begin{tabular}{|c|c|c|}
\hline Age Category & Number & Percent \\
\hline $18-25$ & 744 & $87 \%$ \\
\hline $26-30$ & 56 & $6.5 \%$ \\
\hline $31-40$ & 42 & $5 \%$ \\
\hline $40<$ & 2 & $0.23 \%$ \\
\hline
\end{tabular}

Table (2) The number of participating students from different colleges.

\begin{tabular}{|l|c|c|}
\hline \multicolumn{1}{|c|}{ Colleges } & Number & Percent \\
\hline College of Sciences & 40 & $4.33 \%$ \\
\hline College of Engineering & 21 & $2.28 \%$ \\
\hline College of Business Administration & 18 & $1.95 \%$ \\
\hline College of Architecture and Planning & 70 & $7.58 \%$ \\
\hline College of Nutrition and Agriculture Sciences & 23 & $2.49 \%$ \\
\hline College of Computer Sciences and Information & 14 & $1.52 \%$ \\
\hline College of Pharmacy & 98 & $10.62 \%$ \\
\hline College of Nursing & 73 & $7.91 \%$ \\
\hline College of Dentistry & 2 & $0.22 \%$ \\
\hline College of Applied Medical Sciences & 60 & $6.50 \%$ \\
\hline College of Medicine and University Hospitals & 1 & $0.11 \%$ \\
\hline College of Prince Sultan for Emergency Medi- & 49 & $5.31 \%$ \\
\hline cal Services & 10 & $1.08 \%$ \\
\hline College of Arts & 6 & $0.65 \%$ \\
\hline College of Education & 6 & $0.65 \%$ \\
\hline College of Tourism and Archeology & 27 & $2.93 \%$ \\
\hline College of Languages and Translation & 47 & $5.09 \%$ \\
\hline Institute of Arab Linguistics & 1 & $0.11 \%$ \\
\hline College of Law and Political Sciences & 0 & $0.00 \%$ \\
\hline College of Sports Sciences and Physical Activity & & \\
\hline
\end{tabular}

Table (3) Student GPAs

\begin{tabular}{|c|c|}
\hline GPA & Percent \\
\hline $5-4.50$ & $48.18 \%$ \\
\hline $4.49-3.75$ & $34.65 \%$ \\
\hline $2.75-3.74$ & $12.28 \%$ \\
\hline $2-2.74$ & $3.54 \%$ \\
\hline
\end{tabular}

achievement from geographic, psychological, cultural, and behavioral perspectives.

Table (6) provides the opinions of the participants on the effect of housing location distance from the university on their academic achievement. As evident, $39.49 \%$ responded that there is an effect, while $60.51 \%$ do not believe there is an effect. When asking participants if the distance of the university from their housing location affected their enrollment in the university, 58.64\% responded, "Yes, it did," while $42.36 \%$ answered, "No, it did not."

Table (4): The effect of student housing location on obligation to attend lectures on time

\begin{tabular}{|l|c|c|}
\hline \multicolumn{1}{|c|}{ Criteria } & $\begin{array}{c}\text { Influence } \\
\text { Extent }\end{array}$ & Percent \\
\hline $\begin{array}{l}\text { Influence of housing location on attending } \\
\text { lectures on time }\end{array}$ & Yes & $68.42 \%$ \\
\hline $\begin{array}{l}\text { Influence of housing location on attending } \\
\text { activities held by the university }\end{array}$ & Yes & $31.58 \%$ \\
\hline $\begin{array}{l}\text { Influence of housing location on visiting the } \\
\text { library and other university facilities }\end{array}$ & No & $36.95 \%$ \\
\hline
\end{tabular}

Table (5): Students' weekly number of times delayed for lectures

\begin{tabular}{|c|c|}
\hline Times Delayed & Percent \\
\hline Once a week & $44.19 \%$ \\
\hline times a week 3-2 & $26.99 \%$ \\
\hline More than 5 times a week & $3.19 \%$ \\
\hline Other & $25 \%$ \\
\hline
\end{tabular}

Table (6): Students' opinions about the influence of housing location distance from the university on their academic achievement and enrollment in the university

\begin{tabular}{|l|c|c|}
\hline \multicolumn{1}{|c|}{ Criteria } & $\begin{array}{c}\text { Influence } \\
\text { Extent }\end{array}$ & Percent \\
\hline $\begin{array}{l}\text { Students' opinions about the influence of hous- } \\
\text { ing location on academic achievement }\end{array}$ & Yes & $39.49 \%$ \\
\hline $\begin{array}{l}\text { Students' opinions about the effect of having } \\
\text { a university in their city on enrollment at the } \\
\text { university }\end{array}$ & Yes & $50.51 \%$ \\
\hline
\end{tabular}

Figure (1) Number of students according to degree

\section{Number of Students}

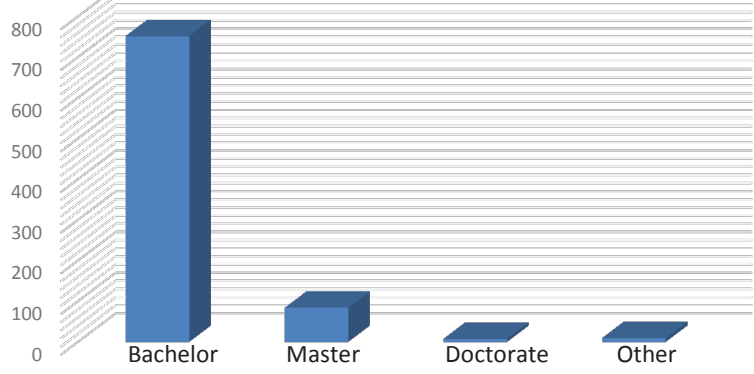


Figure (2): Spatial distribution of King Saud University students in Riyadh, 2016

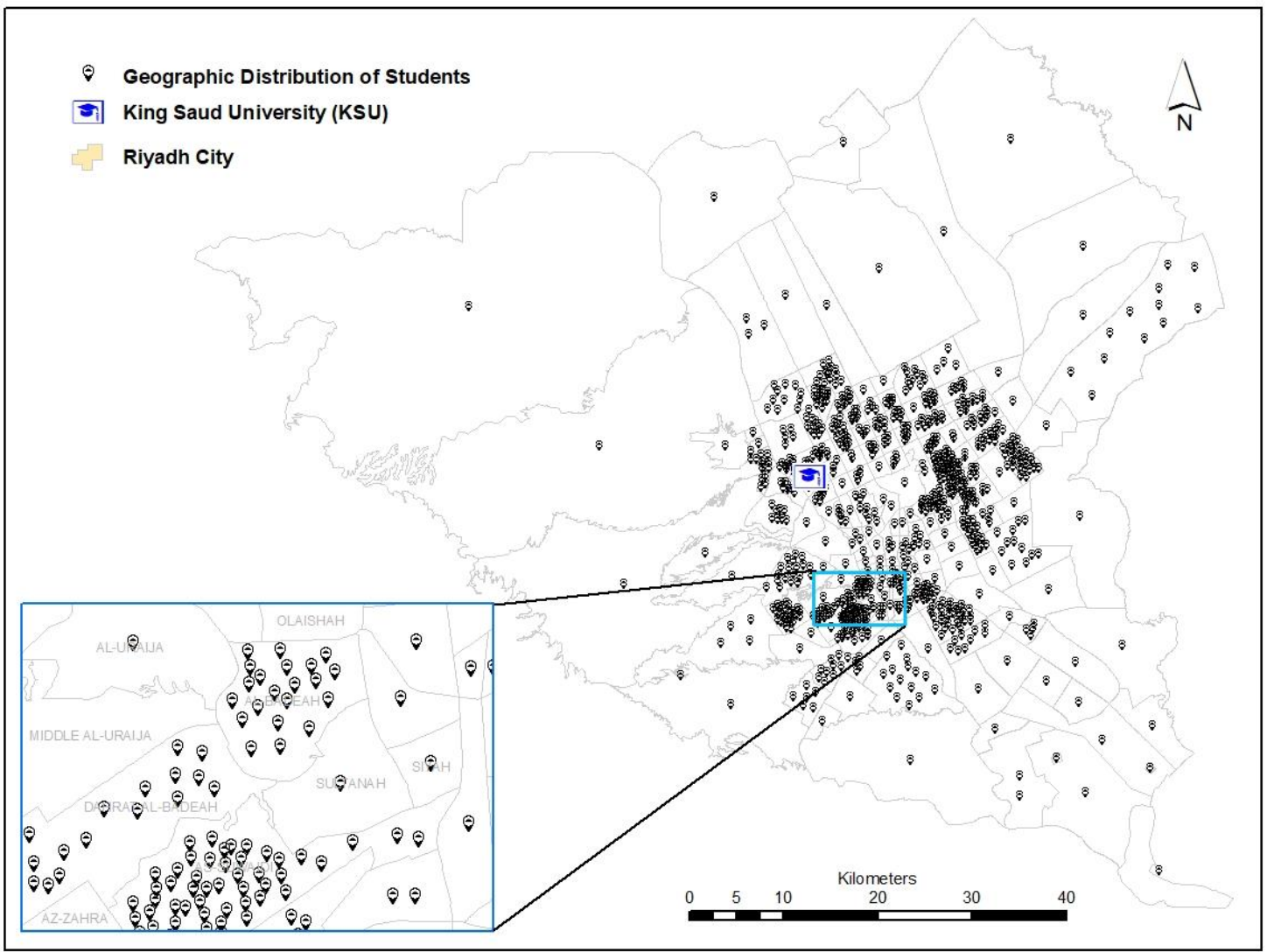

Figure (3): Student density in Riyadh, 2016

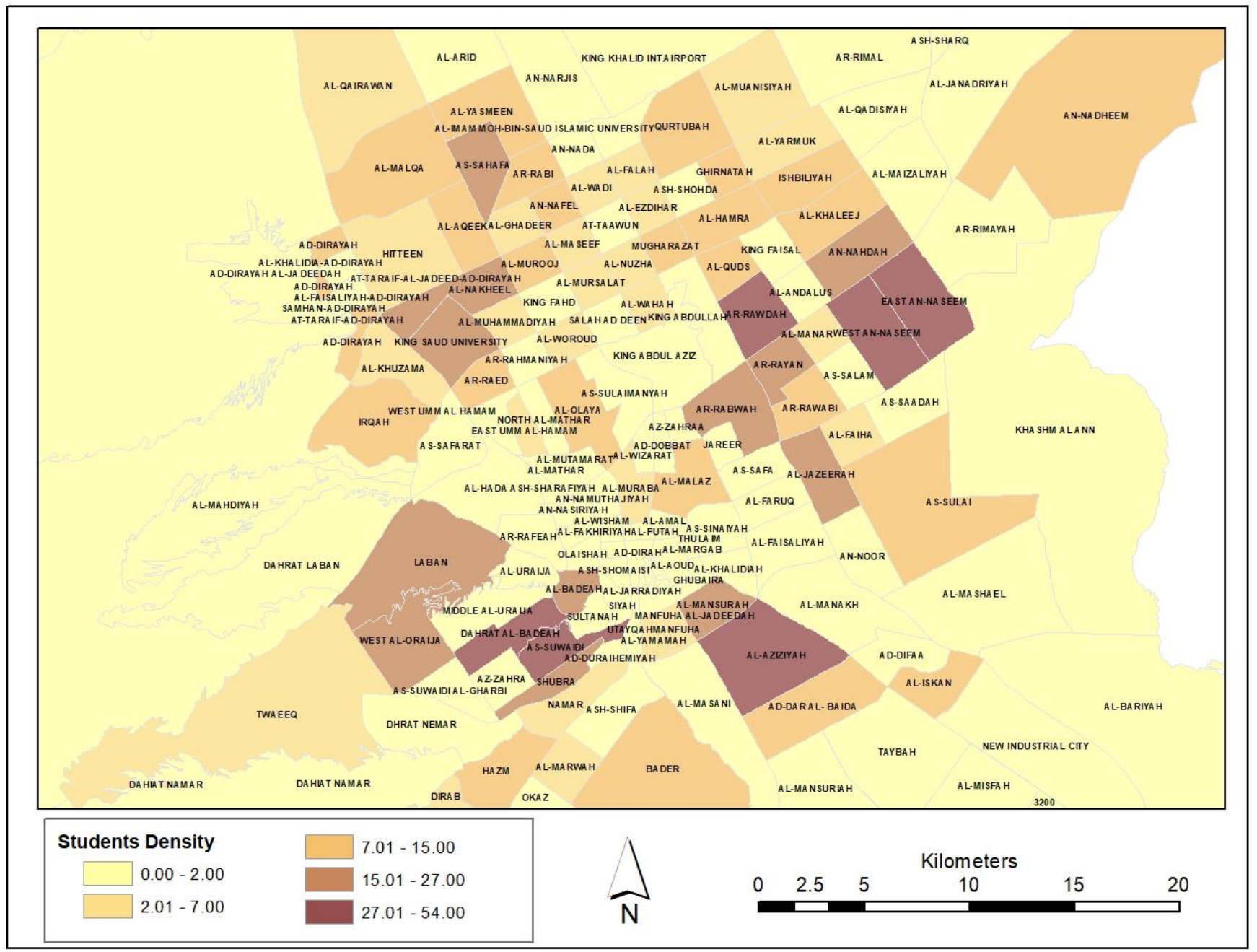


On the other hand, to better understand the research problem, the study surveyed students' opinions about the effect of being located near to the university on academic achievement. In total, $61.67 \%$ noted that education would be better if they lived near to the university, while $36.33 \%$ believed this had no effect. This high percentage shows that housing location has a positive effect on academic achievement, while distance affects other factors leading to loweracademic achievement. Table (7) indicates the relationship between students' number of times delayed and the GPA based on a Pearson correlation coefficient. This indicates a negative correlation relation $(-.204)$ at the evident level of 0.000 between the times delayed and students' GPAs. In other words, the higher the number of delays, the lower students' GPAs, and the greater the effect on students' academic achievement. Figure (4) shows the spatial distribution of students in Riyadh according to GPA. The red and yellow colors indicate that students with low academic achievement are generally distributed a further distance away from the university location, indicating the effect of distance on students' academic achievement.

Distance is one factor affecting students' daily journey time to the university. Table (8) and Figure (5) show the distance in $\mathrm{km}$ between students' location in Riyadh and the university location. In total, $24 \%$ of participants reside $5-10 \mathrm{~km}$ from the university, $14 \%$ reside $25 \mathrm{~km}$ away, while $5 \%$ reside more than $30 \mathrm{~km}$ from the university.

Without considering other factors such as road path, congestion, and stopping, distance may not reflect the reality of the actual journey time taken by students to reach the university. Therefore, a network analysis was conducted to measure the time spent travelling to the university according to the road network. Figure (6) shows the time of students' journeys from their districts of residence to the university. For example, it takes about $35 \%$ of the student participants in this study 40 minutes to reach the university.

\section{Conclusion:}

Geographic constraints in Riyadh affect the academic achievement of students at King Saud University by increasing the number of times they are delayed in attending lectures. As mentioned, $44.19 \%$ of the participants were delayed at least once a week, a very high average that affects student achievement. The study revealed a negative correlation between the times delayed and students' GPAs, which indicates the effect of the times delayed on academic achievement.
Table (7): Pearson correlation coefficient of the relationships between the number of times students are delayed and GPA

\begin{tabular}{|c|c|c|c|}
\hline \multicolumn{4}{|c|}{ Pearson Correlation Coefficient } \\
\hline & & Times Delayed & GPA \\
\hline \multirow{3}{*}{$\begin{array}{l}\text { Times } \\
\text { Delayed }\end{array}$} & Pearson Correlation Value & 1 & $-.204 * *$ \\
\hline & Statistical evident value & & .000 \\
\hline & Sample size & 796 & 796 \\
\hline \multirow{3}{*}{ GPA } & Pearson Correlation value & $-.204 * *$ & 1 \\
\hline & Statistical evident value & .000 & \\
\hline & Sample size & 796 & 796 \\
\hline
\end{tabular}

Table (8): Spatial distance between students' location and the university

\begin{tabular}{|c|c|}
\hline $\begin{array}{c}\text { Distance between students' location and } \\
\text { university }(\mathrm{km})\end{array}$ & Percent \\
\hline $10-5$ & $\% 24$ \\
\hline 15 & $\% 26$ \\
\hline 20 & $\% 30$ \\
\hline 25 & $\% 14$ \\
\hline 30 & $\% 2$ \\
\hline$>30$ & $5 \%$ \\
\hline
\end{tabular}

Figure (4): Spatial distribution of students in Riyadh according to GPA

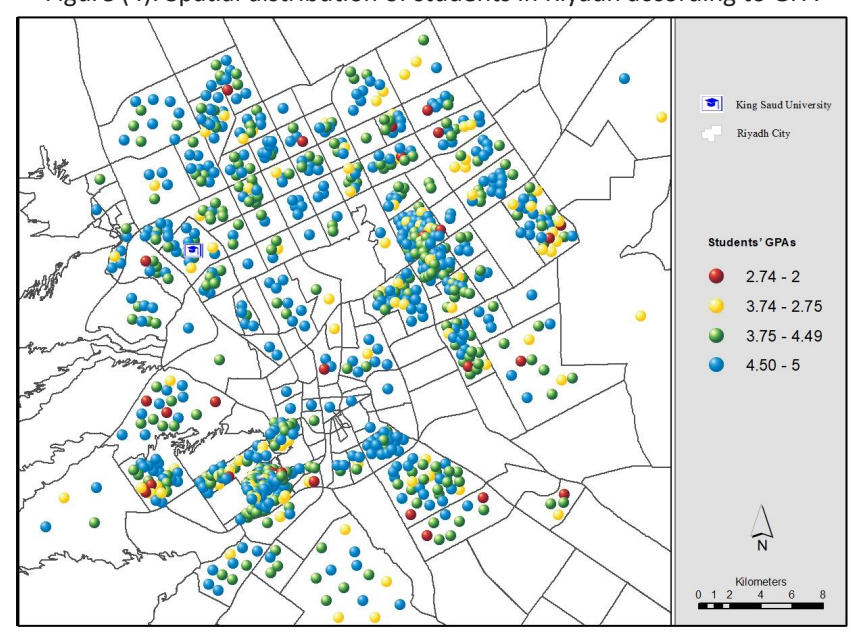

Figure (5): Distance between students' location and the university in Riyadh in km

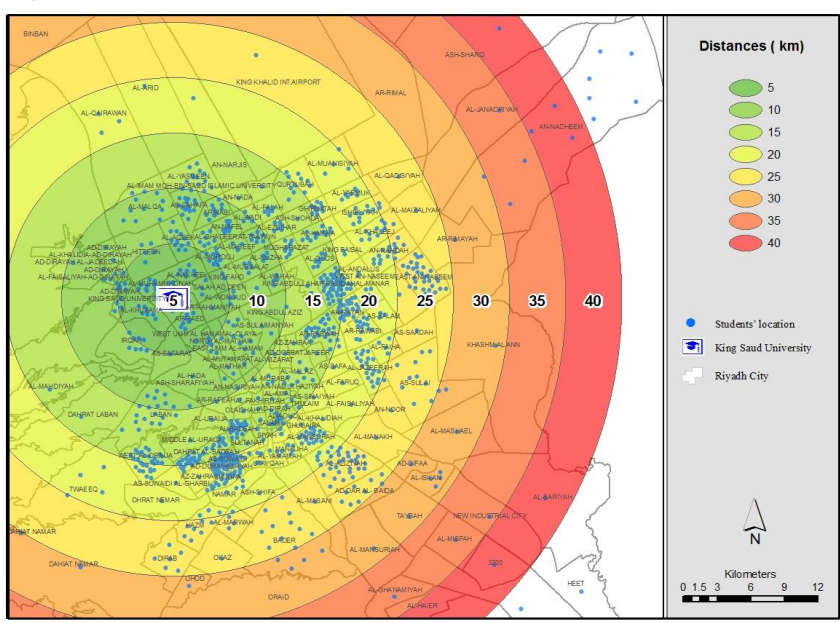


Figure (6): Model of time spent reaching the university

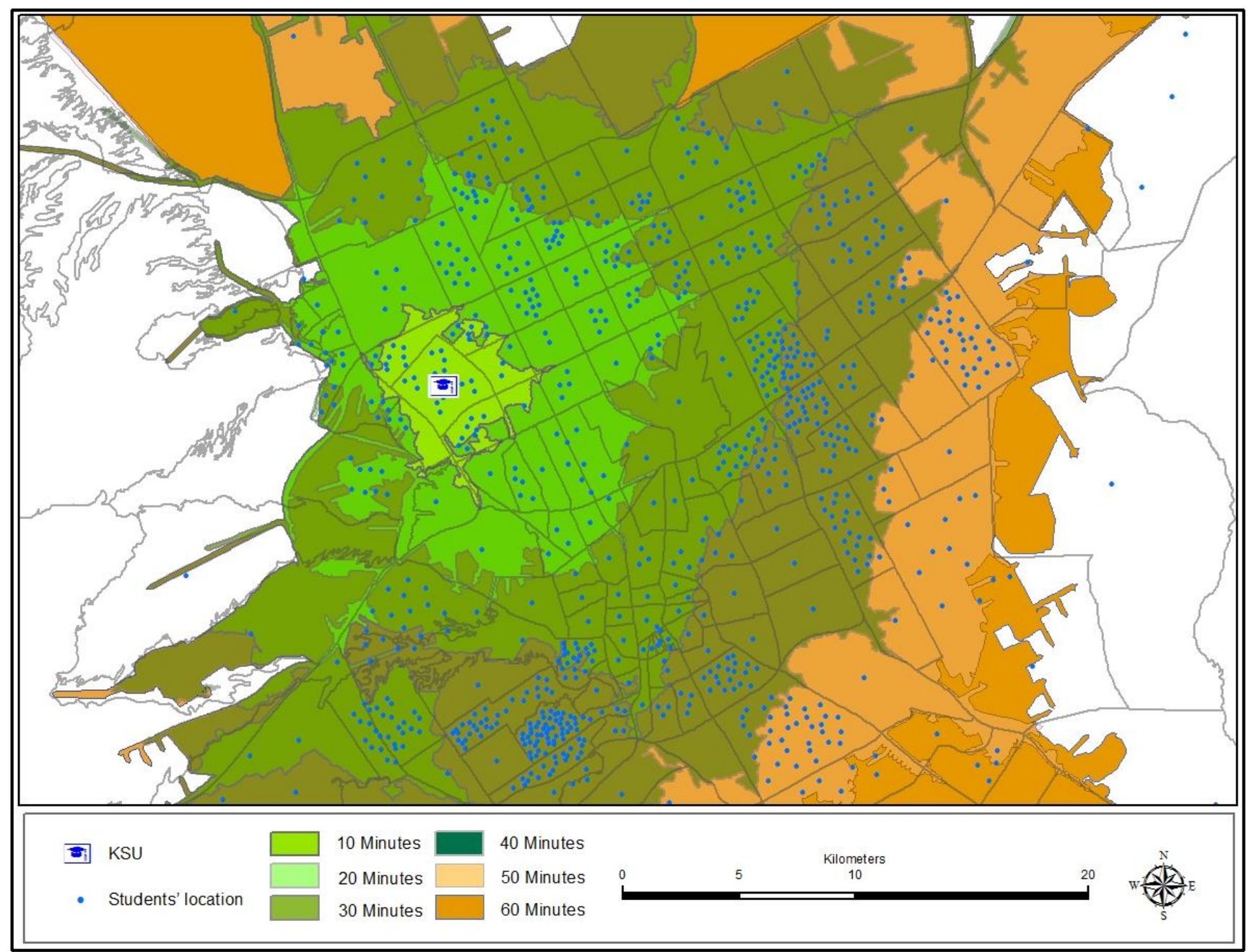

Students' housing location relative to the university affects the academic achievement of $68.42 \%$ of the participants, participation in extracurricular activities of $63.95 \%$ of participants, and visiting the library of $58.16 \%$.

By analyzing the distance between students' housing location and the university, the study revealed that about $30 \%$ of the students' housing are located about $20 \mathrm{~km}$ from the university. Covering this distance in congested traffic in the city, especially during the morning or evening rush hour, increases the time spent reaching the university, which may affect students' punctual attendance of lectures, especially in the morning. The study measured students' daily journey time from their housing location to the university to obtain an accurate measurement of the time spent by conducting a network analysis. The results revealed that about $35 \%$ of the students took about 40 minutes to arrive at the university, and about $8 \%$ spent more than one hour travelling to the university. This average is extremely high, affecting students' academic achievement by increasing the number of times they are delayed in attending lectures. This lateness results in students' missing key concepts in the lecture, which causes physical and mental stress. Based on the results of the study, this paper recommends rescheduling the official working hours of different authorities in Riyadh to reduce the daily journey time in the city. As shown in Table (9), the study proposes that the working hours of Higher Education institutions in Riyadh start at 9:00 am, rather than the current 8:00 am. This will contribute towards decreasing the time spent on the daily journey of university students and employees in the business sector, as well as having other benefits such as reducing environmental risks, accidents, and noise. In addition, it is easy to start education hours one hour later, and it is possible to reschedule lectures to start at that time without needing to reprogram systems, change devices, or other actions.

Table (9): Suggested schedule for employees and students in Riyadh

\begin{tabular}{|c|c|}
\hline Category & Suggested starting time \\
\hline Public Education Students & $7: 00 \mathrm{am}$ \\
\hline Higher Education Students & $9: 00 \mathrm{am}$ \\
\hline Employees and workers & $8: 00 \mathrm{am}$ \\
\hline
\end{tabular}




\section{Acknowledgement:}

The author extends his appreciation to the Deanship of Scientific Research at King Saud University for funding this work through the Research Project No R5-16-01-40

\section{References:}

Alhussien, S.B.N. (2011). The daily resident expiates work journey in the central business region in Riyadh: (Applied Study in Transportation Geography, Series of Geographic Research, the Saudi Geographical Association, Vol. 93).

Card, D. (1995). Using geographic variation in college proximity to estimate the return to schooling. In: Christofides, L.N., Grant, K.E., and R. Swidinsky (Eds). Aspects of Labour Market Behaviour: Essays in Honour of John Vanderkamp, University of Toronto Press, pp. 201-222.

Dickerson, A., Mclntosh, S. (2010). The impact of distance to nearest education institution on the post-compulsory education participation decision, Sheffield Economic Research Paper Series, 2010007.

Do, C. (2004). The effects of local colleges on the quality of college attended. Economics of Education Review, 23, 249-257.

Falch, T., Lujala, P., Strøm, B. (2011). Geographical constraints and educational attainment. Regional Science and Urban Economics, 43 (1), 164-176.

Gibbons, S., Vignoles, A. (2009). Access, choice, and participation in higher education. Centre for the Economics of Education, CEE Discussion Papers 101, London School of Economics and Political Science.

Griffith, A.L., Rothstein, D.S. (2009). Can't get there from here: The decision to apply to a selective college. Economics of Education Review, 28, 620-628.

Kjellström, C., Regnér, H. (1999). The effects of geographical distance on the decision to enroll in university education. Scandinavian Journal of Educational Research, 43, 335-348.

Park, S.J. (2012). Measuring public library accessibility: A case study using GIS. Library \& Information Science Research, 34, 13-21.
Sa, C., Florax, R.J. G.M., Rietveld, P. (2006). Does accessibility to higher education matter? The choice behavior of high school graduates in the Netherlands. Spatial Economic Analysis, 1, 155-174. 